\title{
Contribution to the identities and distribution patterns of Zygaenidae (Lepidoptera) from Romania
}

\author{
Valeriu Albu ${ }^{1}$, Ana Nahirnić-Beshkova ${ }^{2}$
}

(1) 23032 Oak Meadow Ln., Friant, CA 93626, USA, valalbu10@gmail.com; https://orcid.org/0000-0002-6049-4984

(2) National Museum of Natural History, Bulgarian Academy of Sciences, 1 Tsar Osvoboditel Blvd, 1000 Sofia, Bulgaria, ana.diaphana@gmail.com; https://orcid.org/0000-0002-7922-9910

\begin{abstract}
Zygaenid material collected from 25 localities in ten counties of Romania during 1967-2002 was examined. Fifteen species were found, of which Jordanita notata appears to reliably represent the only second population of the species in Romania, while the record of J. budensis seems to be the fifth locality for the country. We discuss several misidentifications of species published in previous publications and list their precise collection places and dates.
\end{abstract}

Keywords: faunistics, Procridinae, Romania, Zygaena

\section{Introduction}

Zygaenidae are a striking group of moths, whose vivid coloration, mostly diurnal habits and sometimes large population size make them very conspicuous and easily recognisable in the field. However, the complete opposite can be said when it comes to differentiating the various species, especially of subfamily Procridinae (the forester moths). Their similarity among adults has led to various confusions in different geographical distribution lists and has prompted the exclusive reliance on genital structures as specific diagnostic criteria. Such a confusion arose from two recently published papers listing forester moths and Zygaena purpuralis (Brünnich, 1763) from Southern Transylvania, Romania (Albu \& Albu, 2018) and from the Vlăsia Plain, Muntenia, Romania (Albu \& Albu, 2020), based on identifications made using superficial characters. One of the present authors, A. N.-B., dissected the specimens discussed in the above papers and pointed out several inexactitudes. Those data on Procridinae should be ignored as we provide here an updated list with the corrected identities of Zygaenidae in the first author's (V.A.) collection. We, hereby, also expand the distributional list of Romanian Zygaenidae with a series of previously unpublished data.

\section{Material and methods}

The sampling was conducted in 25 distinct places, spread out in ten counties. These ranged from an elevation of $50 \mathrm{~m}$ above sea level (a.s.1.) at the Hagieni forest and Călugăreni, and 1265, 1105 and $1020 \mathrm{~m}$ a.s.l. at the Fundata Village, Domogled Mountain and Poiana Braşov, respectively. We listed these localities in Table 1 , providing their elevations and organising them based on their respective counties, along with listing the various species encountered in them. We used the web site "geonames.org" to obtain the correct spelling and elevation for each locality. All material used in this research was obtained through inspecting various flowering plants in diverse habitats during the day. The habitats visited were mountain meadows (Domogled, Poiana Braşov, Tâmpa, Săcele), pastures (Drăuşeni, Drăganu and Teliu Villages, Dealu Monastery), river edges (Pe- 
Table 1. Collecting localities and dates of Zygaenidae.

\begin{tabular}{|c|c|c|c|}
\hline No. & County & Locality and altitude ( $m$ a.s.l.) & Date \\
\hline 1 & Argeş & Drăganu Village, 360 & 03.VII.1998 \\
\hline 2 & Bistriţa-Năsăud & Mocod Village, 300 & 19.VI.2002 \\
\hline $3 a$ & Braşov & Braşov, Bartolomeu, 530 & 30.VII.1967 \\
\hline $3 b$ & & & 02.VII.1968 \\
\hline $4 a$ & & Poiana Braşov, 1020 & 18.VII.1982 \\
\hline $4 b$ & & & 17.VII.1991 \\
\hline $5 a$ & & Tâmpa Mountain, 960 & 18.VII.1969 \\
\hline $5 b$ & & & 25.VII.1981 \\
\hline $5 c$ & & & 30.VII.1981 \\
\hline $5 d$ & & & 17.VII.1991 \\
\hline $5 e$ & & & 14.VII.1998 \\
\hline $6 a$ & & Drăuşeni Village, 480 & 20.VI.1981 \\
\hline $6 b$ & & & 02.VII.1998 \\
\hline $7 \mathrm{a}$ & & Fundata Village, 1265 & 19.VII.1982 \\
\hline $7 b$ & & & 13.VII.1998 \\
\hline 8 & & Hoghiz, Bogata forest, 464 & 11.VII.1998 \\
\hline $9 a$ & & Săcele, Piatra Mare Mountain, 650 & 18.VII.1969 \\
\hline $9 b$ & & & 25.VII.1982 \\
\hline $10 \mathrm{a}$ & & Sânpetru, Lempeş Hill, 528 & 14.VII.1979 \\
\hline $10 \mathrm{~b}$ & & & 23.VII.1981 \\
\hline 11 & & Teliu, Întorsurii Mountain, 543 & 02.VII.1978 \\
\hline 12 & & Vlădeni, 542 & 01.VII.1978 \\
\hline 13 & Caraş-Severin & Băile Herculane, 168 & 18.VI.1986 \\
\hline 14 & & Băile Herculane, Crucea Albă, 529 & 02.VII.1996 \\
\hline $15 \mathrm{a}$ & & Băile Herculane, Domogled Mountain, 1105 & 03.VII.1981 \\
\hline $15 b$ & & & 25.VI.1982 \\
\hline $15 \mathrm{c}$ & & & 21.IX.1982 \\
\hline 16 & & Băile Herculane, Pecinişca, 134 & 28.VI.1998 \\
\hline 17 & Constanţa & Hagieni forest, Mangalia, 50 & 25.V.1982 \\
\hline 18 & Covasna & Breţcu Village, 600 & 23-24.VII.1982 \\
\hline 19 & & Vâlcele Village, 640 & 19.VI.1981 \\
\hline $20 \mathrm{a}$ & Dâmboviţa & Târgovişte, Dealu Monastery, 300 & 16.VI.1981 \\
\hline $20 b$ & & & 17.VI.1982 \\
\hline 21 & Giurgiu & Călugăreni, 50 & 11.VII.1982 \\
\hline 22 & Ilfov & Bucureşti, Andronache forest, 80 & 17.VII.1981 \\
\hline $23 \mathrm{a}$ & & Bucureşti, Pasărea forest, 71 & 14.VIII.1974 \\
\hline $23 b$ & & & 16.VII.1981 \\
\hline 24 & & Chitila Village, 90 & 15.VII.1978 \\
\hline 25 & Neamts & Potoci Village, 577 & 12.VI.2002 \\
\hline
\end{tabular}

cinişca, Călugăreni), forest clearings and edges (Andronache, Pasărea, Hagieni and Bogata forests, Lempeş Hill), fields, gardens and roadside stretches, especially in villages (Mocod, Potoci and Brețcu Villages) and areas disturbed by anthropogenic activities (livestock grazed fields in Vlădeni, Vâlcele and Fundata
Villages, vacant lots in Chitila and Braşov). Capture dates for the specimens in this study stretch from 1967 to 2002 .

Preliminary identification based on habitus was done according to Naumann et al. (1999) and de Freina \& Witt (2001). Re-determination was done by A. N.-B. 


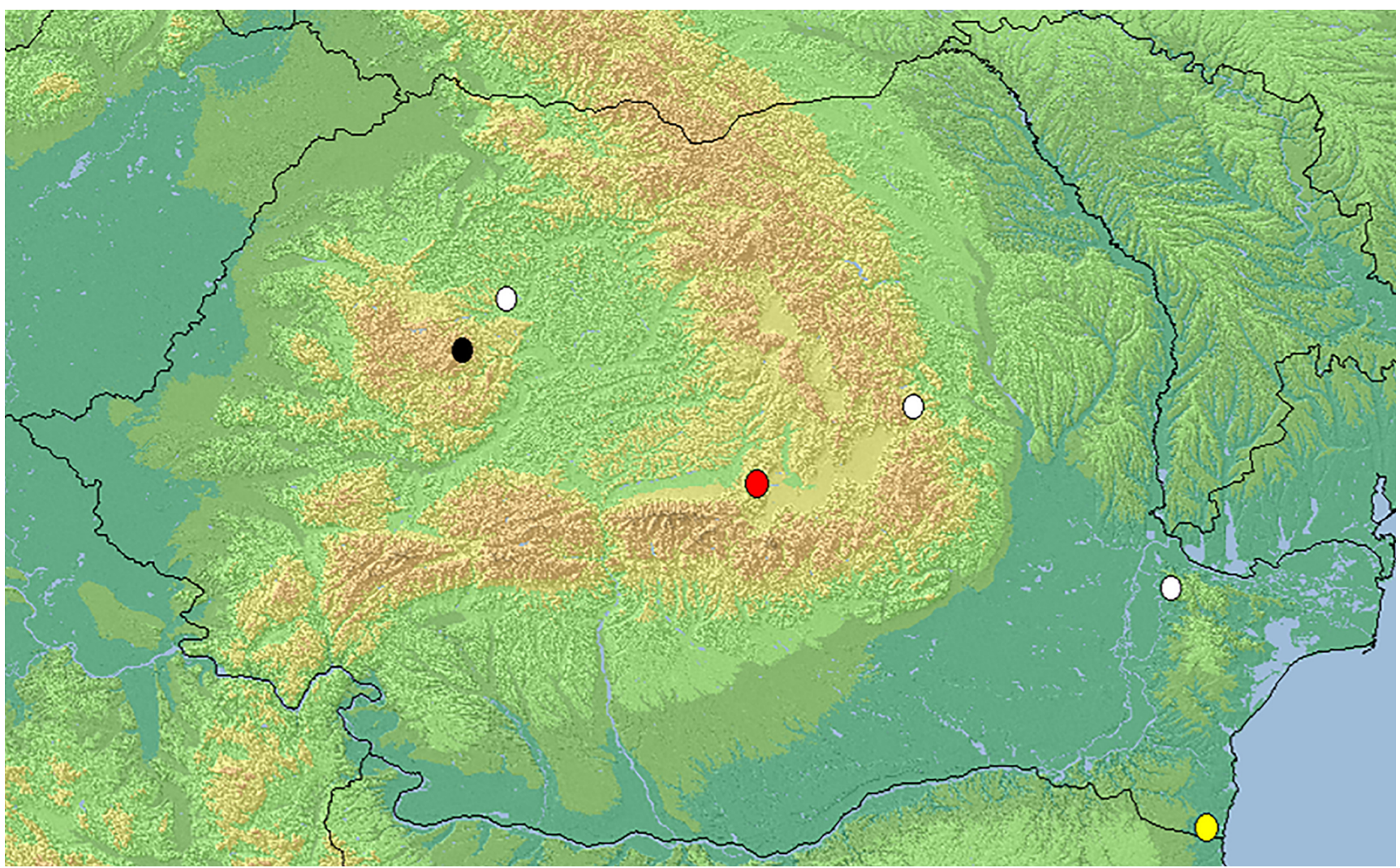

Fig. 1. Map of distribution of Jordanita notata (Zeller, 1847) and J. budensis (Speyer \& Speyer, 1858) in Romania. Black dot $-J$. notata published record, red dot $-J$. notata new record, white dots $-J$. budensis published records, yellow dot $-J$. budensis new record. One white dot covers two very close localities.

on the basis of habitus for several uncertain specimens of Zygaena, habitus and genitalia for Procridinae and exclusively by genitalia dissection for $Z$. purpuralis. Genitalia dissections were done according to Robinson (1976). Abdomina and genitalia are preserved in micro vials filled with glycerol.

\section{Results}

List of species with the number of locality where they were recorded as presented in Table 1.

\section{Procridinae}

Rhagades pruni ([Denis \&Schiffermüller], 1775): 2. Adscita statices statices (Linnaeus, 1758): 1, 2, 12, 19. Jordanita budensis (Speyer \& Speyer, 1858): 17. J. notata (Zeller, 1847): 12.

J. chloros (Hübner, [1813]): 5b, 15a.

J. globulariae (Hübner, 1793): 2, 6b, 11, 25.

\section{Zygaeninae}

Zygaena purpuralis (Brünnich, 1763): 2, 3b, 5a, 5d, $7 \mathrm{a}, 7 \mathrm{~b}, 9 \mathrm{a}, 14,18,23 \mathrm{a}$.

Z. carniolica (Scopoli, 1763): 10a.

Z. viciae ([Denis \&Schiffermüller], 1775): 2, 7b, 25.

Z. loti ([Denis \&Schiffermüller], 1775): 2, 3a, 5b, 5d, 5e, 6a, 7b, 10b, 20a, 20b, 21, 23b, 25.

Z. osterodensis Reiss, 1921: 15b.

Z. ephialtes istoki Silbernagel, 1944: 21, 22.

Z. ephialtes retyesati Holik, 1958: 5e.

$Z$. angelicae Ochsenheimer, 1808: 5c, 5e, $15 \mathrm{~b}$.

Z. filipendulae (Linnaeus, 1758): 4a, 4b, 6a, 6b, 7b, 8, $9 \mathrm{~b}, 13,15 \mathrm{a}, 15 \mathrm{c}, 16,17,24$.

Z. lonicerae (Scheven, 1777): 18.

During this study, we recorded 111 specimens of family Zygaenidae pertaining to 15 species. Of these, 16 individuals of six species were of Procridinae and 95 specimens from ten species were of Zygaeninae. The most abundantly encountered species were $Z$. fili- 
pendulae, Z. loti and Z. purpuralis (with 29, 25 and 23 specimens, respectively), representing subfamily $Z y$ gaeninae. The representatives of Procridinae were much less numerous. The most commonly encountered species of this group, J. globulariae and A. statices were represented by six and five specimens, respectively. The most frequently collected species were also the most widespread ones. Z. loti and Z. filipendulae were encountered at ten localities each, while $Z$. purpuralis at eight localities. An ungrazed and unmowed field on the outskirts of the Mocod Village contained the highest number of species, six. This was followed by the undisturbed meadows in the Tâmpa and Domogled Mountains (including Crucea Albă) with five species each. The places with severe anthropogenic disturbance, e.g. urbanisation (Chitila), agriculture (Dealu Monastery) or livestock overgrazing (Drăganu, Teliu, Vâlcele), were the most species-poor localities with only one species being recorded at each of them.

The earliest season record we had was that of a specimen of $J$. budensis from the Hagieni forest on May 25 th. In June, we recorded nine species out of 33 specimens. In July, the assemblages were the most diverse and abundant, with 75 specimens representing 13 species. On the other hand, in August and September each one specimen was recorded, Z. purpuralis and Z. filipendulae, respectively.

\section{Discussion}

The last comprehensive catalogue of Romanian Lepidoptera (Rákosy et al., 2003), records 29 species of family Zygaenidae from Romania (12 species of Procridinae and 17 species of Zygaeninae). However, the authors cast doubts in their notes about the correct identities of several of the listed species, especially the ones from the older collections, which have not been dissected. Of those 29 species three should not be considered as members of the Romanian fauna: Jordanita tenuicornis (Zeller, 1847), Zygaena cynarae (Esper, 1789) and Z. trifolii (Esper, 1783). Adscita obscura (Zeller, 1847) is the most recent addition for Romania (Guenin, 2019). At present, 27 species of Zygaenidae are confirmed for Romania.

All records from Transylvania presented in our paper were published in Albu \& Albu (2018). However, species of Procridinae (with exception of J. chloros, which is easy to determine on the basis of its habitus, unless it is very worn) and Z. purpuralis should not be considered correct because they were not determined according to genitalia. Moreover, two specimens of $Z$. angelicae from Tâmpa were wrongly reported as $Z$. loti and $Z$. viciae, while $Z$. lonicerae from the Breţcu Village was misidentifies as $Z$. angelicae. All other specimens were correctly determined. In Albu \& Albu (2020), several specimens of Zygaenidae were reported only for the counties of the Vlăsia Plain without mentioning the exact localities. In that paper $A$. statices and $Z$. purpuralis were determined on the basis of habitus. In the present study, we provide additional information such as precise locality and date.

J. notata - This species was reported from Ineu (Arad County) by Căpuşe \& Kovács (1987) and Bădeni (Cluj County) by Mihuț (1997), but specimens were not dissected, so their identity remains in doubt (Rákosy et al., 2003). The first specimen of J. notata to be confirmed through genital dissection was collected in the Apuseni Mountains, around the village of Băişoara (Cluj County) at an elevation of $1200 \mathrm{~m}$ a.s.l. in 2002 (Rákosy et al., 2003). Craioveanu \& Rákosy (2011) reported a series $J$. notata from the same locality. Our specimen from Vlădeni (Braşov County), collected in 1978, represents the only reliable record of this species outside the Apuseni Mountains population (Fig. 1).

J. budensis - This is a widely distributed but local species. In Romania it has been reported from Agapia (Neamţ County), Slănic-Moldova (Bacău County) and Fânațele Clujului - Copârșaie (Cluj County) by Popescu-Gorj (1964), Fânațele Clujului (Cluj County) by Popescu-Gorj (1964) and Rákosy (1987) and from Greci (Tulcea County) by Rákosy \& Wieser (2000). Further reports of $J$. budensis from Caradja (1895-1896), Caradja (1934) and Czekelius (1934) do not contain information on determination methods; they are from the time when genitalia examination was not a common practice and the authors were not $\mathrm{zy}$ gaenid specialists, thus we consider records of $J$. budensis mentioned therein as not reliable. The adult is on the wing from April to July. In that respect, the specimen from Agapia (recorded in August) seems very unusual for an elevation of about $500 \mathrm{~m}$. The image of that specimen from the collection of Ostrogovich in Bucharest shows clearly that it belongs to the genus Adscita Retzius, 1783. The specimen from Slănic-Moldova is confirmed as $J$. budensis. In the collection of Delvig, there is one more record of this species from Băile Geoagiu (Hunedoara County) published by Ciochia \& Barbu (1980). However, according to the report, 


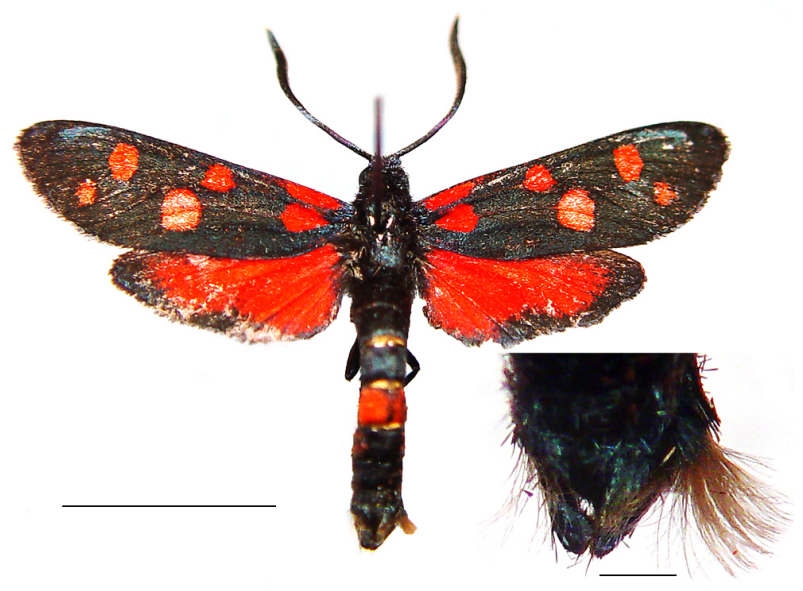

Fig. 2. Zygaena ephialtes retyesati Holik, 1948: adult and the tip of the abdomen with coremata. Scales $=1 \mathrm{~cm}$ and $1 \mathrm{~mm}$, respectively.

this is a female and females of Procridinae (with rare exceptions) are impossible to identify without genital dissection. A search of the collection of Delvig housed in the Braşov County Museum of History showed that there is not a single specimen of Procridinae currently present in the collection. Some of the species that were difficult to identify were sent out by Alexandru Barbu for identification help, but it is not known to whom (Székely, personal communication). We do not know whether this specimen has been dissected or not. This makes our record from the Hagieni forest the fifth reliable locality for Romania and only the second for Dobrogea, along with the specimen from Greci (Fig. 1).

Z. purpuralis $-Z$. purpuralis complex is a very problematic group, which can be distinguished only by genitalia, larval coloration and larval host-plant (Hofmann \& Tremewan, 2017; Nahirnić, 2019). In many papers listing species of this complex, the determination method is not mentioned and so is the case for the majority of papers concerning Romania. In Romania, two cryptic species are reported: Z. purpuralis and $Z$. minos ([Denis \& Schiffermüller], 1775). Zygaena purpuralis is a common species but not all its literature records should be accepted as correct. The only sources known to us that provide appropriate evidence of $Z$. $m i-$ nos in Romania are Naumann et al. (1983), Rákosy \& Lüthi (1995) and Rákosy \& Wieser (2010). The expectancy of the third species, Z. diaphana Staudinger, 1887 should not be underestimated. The nearest known localities of this species are in eastern Serbia and western
Bulgaria (Nahirnić, 2019; Nahirnić et al., 2019) and south-eastern Bulgaria (Nahirnić et al., in press). It could possibly inhabit steppe or steppe-like grasslands with abundance of Eryngium campestre L., its larval host-plant.

Z. ephialtes $-Z$. ephialtes retyesati is a subspecies restricted to the southern and eastern Carpathian Mountains in Romania (including Apuseni Mountains). Here it has polymorphic populations, mainly red or red to orange-red five-spotted peucedanoid, but also yellow and orange ephialtoid forms, with a broad hind wing border (Hofmann \& Tremewan, 2020). Illustrations of this subspecies are given in de Freina \& Witt (2001) and Hofmann \& Tremewan (2020). We could not find any other images in online scientific literature or in other literature sources on Zygaenidae of Romania; therefore, we provide the photo of our specimen from the Tâmpa Mountain (Fig. 2). From many publications for Romania (as well as for the whole range of the species), it is not clear which subspecies is concerned. We emphasise that sampling of only one or a few specimens in order to prove the presence of the species at a certain locality is not enough for the subspecific determination. On the other hand, we do not encourage the collectiion of large series. It can be very helpful to take photos or release specimens after the wing pattern is noted. Precise information is very important for determining the distributional patterns of this highly polymorphic species and its evolutionary history. We illustrate the coremata of our Z. ephialtes from Tâmpa Mountain (Fig. 2) as coremata images of Zygaena species have not been found online at the time of the preparation of the manuscript.

Literature records of Procridinae and Zygaena purpuralis complex in Romania should be taken with caution and collections should be re-examined, especially through dissection of genitalia. Reliable identifications can show different distribution patterns than those currently published in the literature for the species of $\mathrm{Zy}$ gaenidae of Romania.

\section{Acknowledgements}

We thank Mihai Stănescu ("Grigore Antipa" National Museum of Natural History, Bucharest) for his kindness and for providing photos of specimens from the Ostrogovich collection and Székely Levente (Săcele, Romania) for providing the precise information on the Delvig collection. Likewise, we thank Lászlo Rákosy 
(Cluj-Napoca, Romania) and Zoltán Kovács (Miercurea Ciuc, Romania) for making available to us the pages regarding Zygaenoidea from the publication by Căpuşe \& Kovács (1987), as well as information about the identification process in the Diószeghy collection.

\section{References}

Albu V., Albu S. 2018 Contributions to the knowledge of the Lepidoptera fauna of Southern Transylvania. Entomologica Romanica 22: 13-56.

Albu V., Albu S. 2020 Contributions to the knowledge of the Lepidoptera of Vlăsia Plain (Muntenia, Romania). Entomologica Romanica 24: 5-18.

Caradja A. 1895-1896 Die Grosschmetterlinge des Königreiches Rumänien. Deutsche Entomologische Zeitschrift herausgegeben von der Gesellschaft Iris zu Dresden in Verbindung mit der Deutschen Entomologischen Gesellschaft zu Berlin 8: 1-102, 9: 1-112.

Caradja A. 1934 Neuer Beitrag zur Kenntnis der Lepidopteren-Fauna Rumäniens. Deutsche Entomologische Zeitschrift Iris, Dresden 48: 185-191.

Căpuşe I., Kovács A. 1987 Catalogul colecției de lepidoptere "László Diószeghy" de la Muzeul Județean Covasna, Sfântul Gheorghe. Institutul de Speologie "Emil Racoviță", Bucureşt, 397 pp.

Ciochia V., Barbu A. 1980 Catalogul colecţiei de lepidoptere "N. Delvig" a Muzeului Județean Braşov. Cumidava 12 (2): 1-149.

Craioveanu C., Rákosy L. 2011 Fauna de lepidoptere din habitate semi-naturalemontane ale zonei Muntele Băişorii (jud. Cluj). Buletinul de informare Entomologică 22: 89-103.

Czekelius D. 1934 Beiträge zur Schmetterlings fauna Siebenbürgens (IX). Verhandlungen und Mitteilungen des Siebenbürgischen Vereins für Naturwissenschaften zu Hermannstadt 83-84: 59-69.

De Freina J.J., Witt T.J. 2001 Die Bombyces und Sphinges der Westpalaearktis, Band 3, Zygaenoidea: Zygaenidae. Edition Forschung und WissenschaftVerlag GmbH, München, 575 pp.

Guenin R. 2019 Adscita (Adscita) obscura (Zeller, 1847) (Lepidoptera: Zygaenidae, Procridinae) Erstnachweis für Rumänien. Entomologica Romanica 23: 5-12.

Hofmann A.F., Tremewan W.G. 2017 The Natural History of Burnet Moths (Zygaena Fabricius 1775)
(Lepidoptera: Zygaenidae). Part I. Museum Witt, Munich, $361 \mathrm{pp}$.

Nahirnić A. 2019 Zygaena diaphana Staudinger, 1887 bona species (Lepidoptera: Zygaenidae). SHILAP Revista de Lepidopterología 47 (186): 341-347.

Nahirnić A., Jakšić P., Marković M., Zlatković B. 2019 New Data on Rare Zygaenidae (Lepidoptera) and Their Habitats in Eastern Serbia. Acta zoologica bulgarica 71 (4): 491-500.

Nahirnić A., Toshova T.B., Beshkov S. (in press) New data for Bulgarian Zygaenidae (Lepidoptera) from Sakar Mountain. Acts zoologica bulgarica.

Naumann C.M., Richter G., Weber U. 1983 Spezifität und Variabilität im Zygaena purpuralis Komplex (Lepidoptera, Zygaenidae). Theses Zoologicae 2: $1-263$.

Rákosy L. 1987 A valuable collection of Lepidoptera in the Zoological museum of the University in ClujNapoca (Part I). Studia Universitatis Babeş-Bolyai, Biologia 32 (2): 55-58.

Rákosy L., Goia M., Kovács, Z. 2003 Verzeichnis der Schmetterlinge Rumäniens. Societatea Lepidopterologică Română, Cluj-Napoca, 447 pp.

Rákosy L., Lüthi A. 1995 Zygaena (Mesembrynus) minos ([Denis \& Schiffermüller], 1775) a new species for the Romanian fauna. Buletin informare Societatea Lepidopterologică Română 6 (3-4): 171-172.

Rákosy L., Wieser C. 2000 Das Măcin Gebirge (Rumänien, Nord-Dobrudscha) - Ein durch hohe Biodiversität gekennzeichnetes Refugium reliktärer Arten. Carinthia II 190/110: 7-116.

Rákosy L., Wieser C. 2010 Diversität bei Schmetterlingen (Lepidoptera) im Gebiet von Rimetea (Eisenburg) (Transsylvanien, Rumänien). Buletin de Informare Entomologică 21: 36-83.

Robinson G. 1976. The preparation of slides of Lepidoptera genitalia with special reference to the Microlepidoptera. Entomologist's Gazette 27: 127-132.

Székely L., Cernea E. 2007 The Catalogue of "Mircea Brătăşeanu" Lepidoptera collection. Braşov County Council \& Brașov County History Mu- 